\title{
A 50-Year-Old Patient with Homozygous Familial Hypercholesterolemia
}

\author{
Kenji Ishil, ${ }^{1, *}$ Tadashi Matsumura, ${ }^{2}$ Kenjirou Hori, ${ }^{2}$ \\ and Toru KITA ${ }^{1}$ \\ ${ }^{1}$ Department of Geriatric Medicine, Faculty of Medicine, \\ Kyoto University, Kyoto 606, Japan \\ ${ }^{2}$ Division of Cardiology, Tenri Hospital, \\ Tenri 632, Japan
}

(Received April 29, 1989)

\begin{abstract}
Summary We report a 50-year-old male with homozygous familial hypercholesterolemia. His plasma cholesterol level was over $600 \mathrm{mg} / \mathrm{dl}$. He had suffered from ischemic heart disease since age 20. Receptor assay utilizing skin fibroblasts revealed that he was a homozygote for receptornegative familial hypercholesterolemia. In addition, his fibroblasts synthesized no immunoprecipitable low-density lipoprotein receptor. Considering his disease, his life is extraordinarily long; this is, in part, attributable to his dietary habits.
\end{abstract}

Key Words: familial hypercholesterolemia, low-density lipoprotein

Familial hypercholesterolemia $(\mathrm{FH})$ is one of the most common genetic disorders affecting man [1]. It is transmitted as an autosomal dominant trait. The gene frequency for heterozygous FH is estimated to be one in 500; and that for the homozygote one in one million. The basic defects associated with this disorder lie in the cell surface receptors for low-density lipoprotein (LDL). The clinical characteristics consist of a high concentration of plasma cholesterol, xanthoma formation, and premature coronary heart disease. Many heterozygous patients suffer from coronary heart disease in the fourth decase, and most of the homozygous patients die of myocardial infarction by age 30 [2]. We studied a 50year-old male with homozygous familial hypercholesterolemia. He is the oldest patient on record with receptor-negative homozygous familial hypercholesterolemia.

*To whom correspondence should be addressed. 


\section{MATERIALS AND METHODS}

Materials. The sources of materials used in this work were as follows: Sodium $\left[{ }^{125} \mathrm{I}\right.$ ] iodide $(17.4 \mathrm{Ci} / \mathrm{mg})$ and $\mathrm{EN}^{3} \mathrm{HANCE}$ from New England Nuclear (Boston, MA), $\left[{ }^{35} \mathrm{~S}\right]$ methionine $(900-1,200 \mathrm{Ci} / \mathrm{mmol})$ from Amersham (Bucks), methionine-free Minimal Essential Medium from Nissui Seiyaku (Tokyo), and goat anti-mouse IgG (Cat. No. 0211-0081) from Cappel (Malvern, PA). A monoclonal antibody (designated IgG-C7) against the bovine adrenal LDL receptor, which cross-reacts well with the human receptor [3], and control monoclonal antibody (designated IgG-2001) were kindly provided by Dr. J.L. Goldstein. Other materials were obtained as previously described [4].

Receptor analysis. Human low-density lipoprotein (LDL, $d=1.019-1.063$ ) and lipoprotein-deficient serum (LPDS, $d>1.215$ ) were prepared by sequential ultracentrifugation [5]. LDL was radioiodinated with [ $\left.{ }^{125 I}\right] \mathrm{Na}$ and IC1 [5]. Skin fibroblasts were obtained from forearm biopsy and cultured in Dulbecco's Modified Eagle's Medium (DMEM) with 10\% fetal calf serum. Cells were prepared $48 \mathrm{~h}$ after incubation in DMEM which contained 10\% LPDS. Cell surface-binding and degradation of $\left[{ }^{125} \mathrm{I}\right] \mathrm{LDL}$ were assayed as described by Goldstein et al. [5].

Biolabeling of receptor with $\left[{ }^{35} S\right]$ methionine. Immunoprecipitation study was performed by the method described by Tolleshaug et al. [3]. In brief, skin fibroblasts prepared in 100-mm Petri dishes were cultured in the presence of 200 $\mu \mathrm{Ci}$ of $\left[{ }^{35} \mathrm{~S}\right]$ methionine. After incubation for $2 \mathrm{~h}$ at $37^{\circ} \mathrm{C}$, each dish was washed with $3 \mathrm{ml}$ of phosphate buffered saline (PBS) and complete DMEM was then added. After incubation for $2 \mathrm{~h}$ at $37^{\circ} \mathrm{C}$, the monolayers were washed twice with $3 \mathrm{ml}$ of PBS. Next, $0.4 \mathrm{ml}$ of ice-cold $10 \mathrm{~mm}$ HEPES buffer ( $\mathrm{pH} 7.4$ ) containing 200 $\mathrm{mM} \mathrm{NaCl}, 2 \mathrm{mM} \mathrm{CaCl}, 2.5 \mathrm{mM} \mathrm{MgCl}_{2}, 1 \mathrm{~mm}$ phenylmethylsulfonyl fluoride in $0.25 \%$ dimethylsulfoxide, $0.1 \mathrm{~mm}$ leupeptin, and $1 \%$ Triton $\mathrm{X}-100$ was added to each dish. The cells were scraped from the dish with a rubber policeman and centrifuged at $100,000 \times \mathrm{g}$ for $30 \mathrm{~min}$ at $4^{\circ} \mathrm{C}$. Each $100,000 \times \mathrm{g}$ supernatant fraction was divided in half, and $0.8 \mathrm{ml}$ of each was mixed with immune complexes consisting of goat-anti-mouse $\mathrm{Ab}$ and IgG-C7 or IgG-2001 as described [3]. The mixture was shaken on a rotator for $1 \mathrm{~h}$ at $4^{\circ} \mathrm{C}$, applied to a discontinuous sucrose gradient (10-50\%) and centrifuged at $30,000 \times g$ for $20 \mathrm{~min}$. After one wash, each precipitate was dissolved in $40 \mu \mathrm{l}$ of water, mixed with an equal volume of buffer containing $20 \%$ glycerol, $0.2 \mathrm{M}$ dithiothreitol, $4.7 \% \mathrm{SDS}$, and $150 \mathrm{~mm}$ Tris at $\mathrm{pH}$ 6.8, and subjected to one-dimensional 7\% SDS-polyacrylamide gel electrophoresis. The gel was then soaked in $10 \%$ trichloroacetic acid, enhanced, and dried. Dried gel was exposed to X-ray film (Kodak XAR-5 film) at $-70^{\circ} \mathrm{C}$ for $72 \mathrm{~h}$.

\section{RESULTS}

\section{Case report}

A Japanese male first exhibited xanthelasmas at the age of 4, and developed 
marked xanthomas in the neck, elbow, and Achilles' tendon in his second decade. Angina followed physical exertion at the age of 20. The frequency of angina increased after the age of 30 . He suffered from myocardial infarction three times: at 38, 42, and 48. He entered Tenri Hospital because of uncontrollable chest pain at the age of 48 , and was referred to Kyoto University with severe hypercholesterolemia and xanthomatosis. All three of his brothers and sisters, except one who had already died, showed signs of familial hypercholesterolemia, i.e., hypercholesterolemia, coronary artery diseases, corneal arcus, and tendon xanthomas (Fig. 1). His plasma cholesterol level was over $600 \mathrm{mg} / \mathrm{dl}$ (Table 1). Plasma levels of apolipoprotein B were increased as much as $417 \mathrm{mg} / \mathrm{dl}$. He had xanthomas in the neck (Fig. 2), bilateral elbow, knee, eyelid, and Achilles' tendon (Fig. 3A). The Achilles' tendon xanthomas was $23 \mathrm{~mm}$ thick (Fig. 3B). The coronary angiogram showed severe stenosis in the three vessels (Fig. 4).

The results of lipoprotein analysis of the patient showed the pattern of type IIb hyperlipoproteinemia (Table 1). Although the table shows hypertriglyceridemia, the level of triglyceride fluctuated occasionally (data not shown).

Binding and degradation of $L D L$

We examined the fibroblasts for binding and degradation of $\left[{ }^{125} \mathrm{I}\right] \mathrm{LDL}$ (Fig. $5 \mathrm{~A}$ and $\mathrm{B})$. Fibroblasts from the patient showed neither binding nor degradation
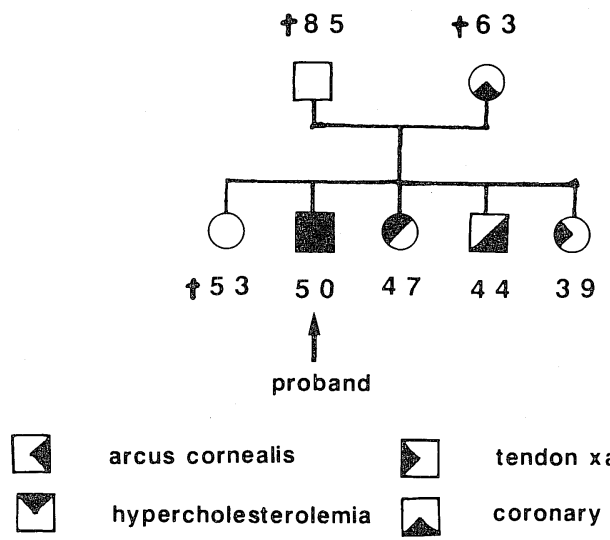

tendon $x$ anthoma

coronary artery disease

Fig. 1. Family pedigree of the patient.

Table 1. Plasma lipid determinations at the time of the first admission.

\begin{tabular}{lcccc}
\hline & $\begin{array}{c}\text { Plasma lipids } \\
(\mathrm{mg} / \mathrm{dl})\end{array}$ & $\begin{array}{c}\text { VLDL } \\
(\mathrm{mg} / \mathrm{dl})\end{array}$ & $\begin{array}{c}\text { LDL } \\
(\mathrm{mg} / \mathrm{dl})\end{array}$ & $\begin{array}{c}\text { HDL } \\
(\mathrm{mg} / \mathrm{dl})\end{array}$ \\
\hline Cholesterol & 604 & 69.9 & 509 & 24.6 \\
Triglyceride & 293 & 129 & 159 & 5.0 \\
Phospholipid & 426 & 30.2 & 335 & 60.4 \\
\hline
\end{tabular}

VLDL, Very low-density lipoprotein; LDL, low-density lipoprotein; HDL, high-density lipoprotein.

Vol. 7, No. 2, 1989 


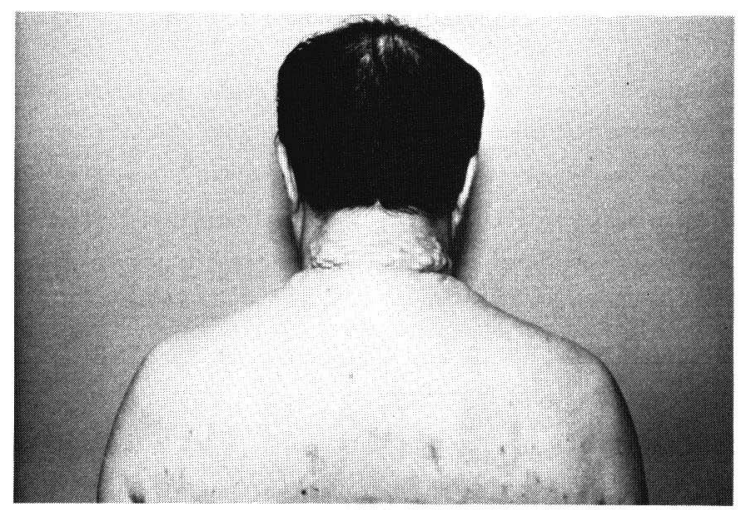

Fig. 2. Xanthoma in the neck.
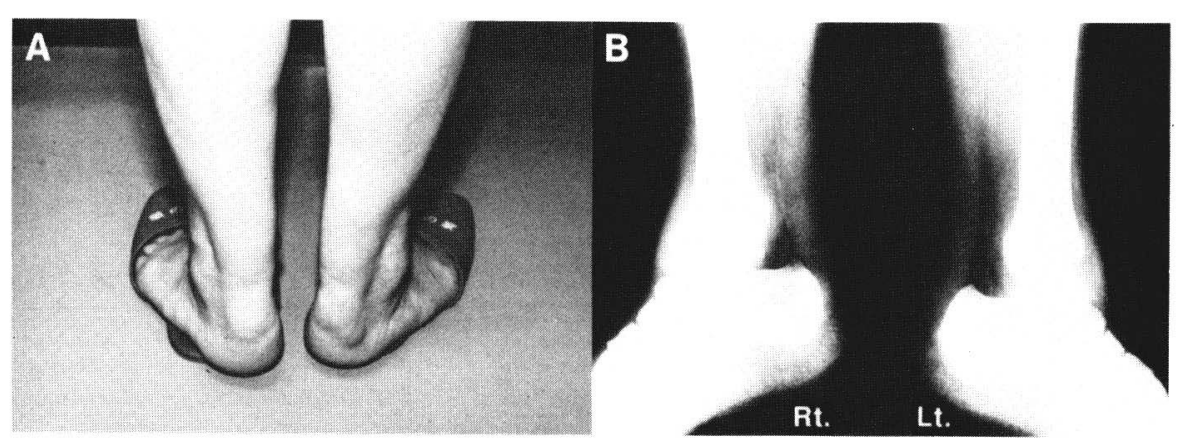

Fig. 3. Xanthoma in the Achilles' tendon.

of $\left[{ }^{125} \mathrm{I}\right] \mathrm{LDL}$, indicating that our patient was a homozygote for receptor-negative familial hypercholesterolemia [1]. Furthermore, the immunoprecipitation study showed that the fibroblasts from the patient produced no protein that precipitated with anti-receptor antibodies (Fig. 6).

\section{DISCUSSION}

This is an unusual case of homozygous familial hypercholesterolemia in the following ways: 1) extraordinarily long life span, 2) onset of first myocardial infarction at 38 years of age, and 3 ) less severe xanthomas than are usually found in this disease. The oldest patient with homozygous familial hypercholesterolemia reported was a 52-year-old Japanese female; however, no receptor analysis was done in that case [6]. In addition, some homozygote cases have been reported to survive for over 40 years; and, although some cases of patients over 50 years old with hypercholesterolemia and xanthomatosis have been reported, the diagnosis of familial hypercholesterolemia has been based upon clinical features [6, 7]. As 


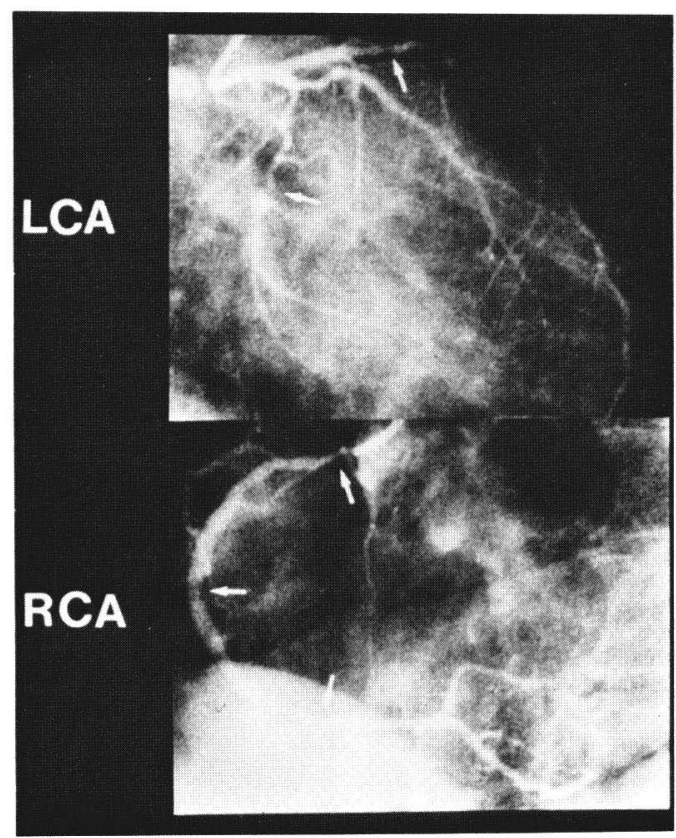

Fig. 4. Coronary angiogram of the patient. Arrows indicate lesions in left anterior descending $(75 \%)$, left circumflex $(99 \%)$, and right $(90,75,75 \%)$ coronary artery, respectively. LCA, Left coronary artery; RCA, right coronary artery.
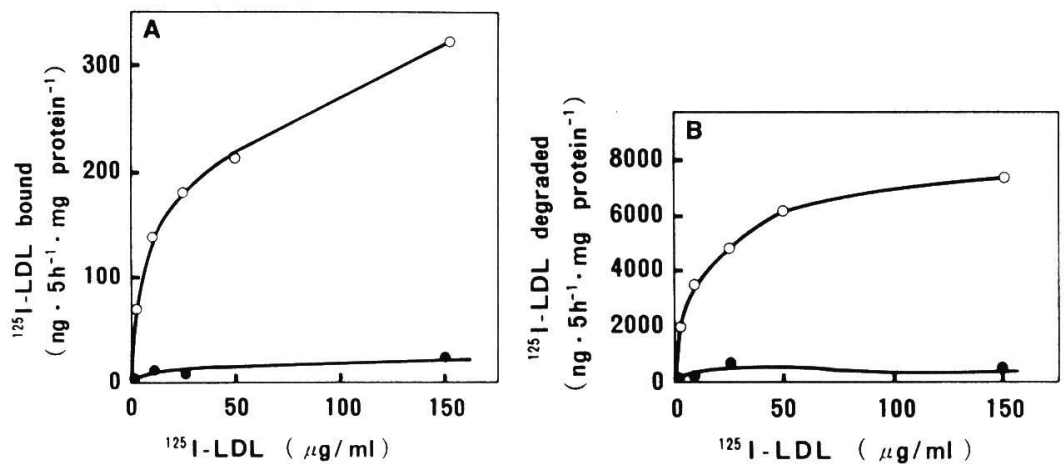

Fig. 5. Cell surface binding (A) and degradation (B) of [ $\left.{ }^{125} \mathrm{I}\right] \mathrm{LDL}$ by the fibroblasts. Each monolayer received $2.0 \mathrm{ml}$ of DMEM and the indicated concentration of $\left[{ }^{125} \mathrm{I}\right] \mathrm{LDL}$ ( 196 $\mathrm{cpm} / \mathrm{ng}$ of protein). After incubation for $5 \mathrm{~h}$ at $37^{\circ} \mathrm{C}$, the amount of heparin releasable radioactivity (A) and the amount of [ $\left.{ }^{125} \mathrm{I}\right]$-labeled acid soluble material in the medium (B) were determined.

heterozygous patients sometimes show fluminant signs of hypercholesterolemia, biochemical assay is nowadays essential for the diagnosis of the homozygote. Our case is the oldest patient with homozygous familial hypercholesterolemia who has 


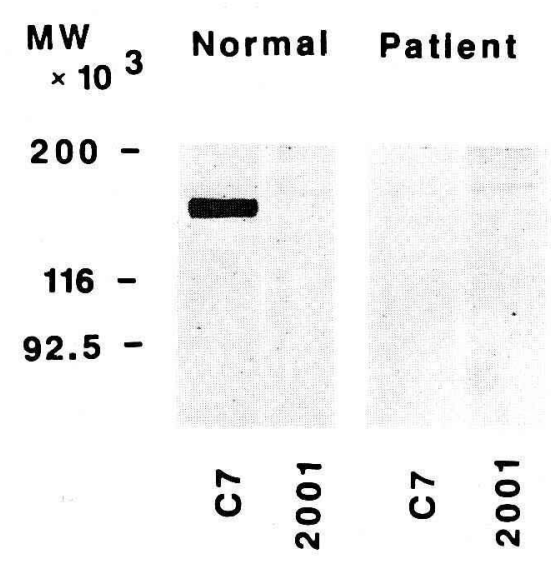

Fig. 6. Incorporation of $\left[{ }^{35} \mathrm{~S}\right]$ methionine into low-density lipoprotein receptors of fibroblasts from a normal subject and from our subject with receptor-negative patient. Monolayers of a healthy control's fibroblasts and of the patient's fibroblasts were pulse-labeled for $2 \mathrm{~h}$ with $\left[{ }^{35} \mathrm{~S}\right]$ methionine and then incubated with unlabeled methionine for $2 \mathrm{~h}$. Cell extracts were immunoprecipitated with monoclonal antibody against LDL (IgG-C7) or nonspecific antibody (IgG-2001) and analyzed by SDS gel electrophoresis and fluorography. Left, Normal subject; right, our patient. Synthesized LDL receptor was indicated as a $160 \mathrm{kDa}$ band. Molecular weight standards are shown at the left.

been diagnosed biochemically.

The reason for his extraordinarily long life span is not known. He was brought up in the rural area of Nara, Japan. His diet was the traditional Japanese diet which is low in fat. High fat and cholesterol in the diet, especially those obtained from animal products, certainly increase the plasma cholesterol level. On the other hand, restricting their intake lowers the plasma cholesterol level. Kita et al. [8] reported that the plasma cholesterol level in Zen monks, who are prohibited from eating animal products, was quite low compared with that of controls. In addition, a homozygous patient with familial hypercholesterolemia, who was treated strictly with diet and drugs, showed a virtually normal coronary angiogram [9]. Recently, Yamashita et al. [10] reported a 31-year-old Japanese female patient with homozygous familial hypercholesterolemia who had no coronary artery disease. They assumed that a strict dietary regimen (low calories and low fat) might have played a role in preventing the development of coronary atherosclerosis.

However, it is difficult to explain our patient's extraordinarily long life span solely on the basis of his dietary habits. His overall environment and lifestyle were probably also responsible. Factors such as occupation, stress, high blood pressure, smoking, and diabetes probably affect coronary disease. In addition, some racial difference might exist between Japanese and Western people, because Japanese cases of homozygous familial hypercholesterolemia are relatively long-lived compared to patients of other races $[1,3,4]$. Our case suggests that some ill- 
defined factors protected the patient from the genetic factors which in other patients have led to coronary death by age 50 .

This research was supported by grants from the Ministry of Education, Science and Culture of Japan (Nos. 62304053, 62619502, 63480270); a research grant for Intractable Diseases from the Ministry of Health and Welfare, Japan; and a research grant for Cardiovascular Diseases (61 C-2) from the Ministry of Health and Welfare, Japan.

\section{REFERENCES}

1. Goldstein, J.L., and Brown, M.S. (1983): Familial hypercholesterolemia, in The Metabolic Basis of Inherited Disease (5th ed.), ed. by Stanbury, J.B., Wyngaarden, J.B., Fredrickson, D.S., Goldstein, J.L., and Brown, M.S., McGraw-Hill, New York, pp. 672-712.

2. Khachadurian, A.K., and Uthman, S.M. (1973): Experiments with the homozygous cases of familial hypercholesterolemia. A report of 52 patients. Nutr. Metab., 15, 132-140.

3. Tolleshaug, H., Goldstein, J.L., Schneider, W.J., and Brown, M.S. (1982): Posttranslational processing of the LDL receptor and its genetic disruption in familial hypercholesterolemia. Cell, 30, 715-724.

4. Kita, T., Yokode, M., Watanabe, Y., Narumiya, S., and Kawai, C. (1986): Stimulation of cholesteryl ester synthesis in mouse peritoneal macrophages by cholesterol-rich very low density lipoproteins from the Watanabe Heritable hyperlipidemic rabbit, an animal model of familial hypercholesterolemia. J. Clin. Invest., 77, 1460-1465.

5. Goldstein, J.L., Basu, S.K., and Brown, M.S. (1983): Receptor-mediated endocytosis of low-density lipoprotein in cultured cells. Methods Enzymol., 98, 241-260.

6. Mabuchi, H., Tatami, R., Haba, T., Ueda, K., Kametani, T., Itoh, S., Koizumi, J., Oota, M., Miyamoto, S., Takeda, R., and Takeshita, H. (1978): Homozygous familial hypercholesterolemia in Japan. Am. J. Med., 65, 290-297.

7. Sprecher, D.L., Schaefer, E.J., Kent, K.M., Gregg, R.E., Zech, L.A., Hoeg, J.M., Mcmanus, B., Roberts, W.C., and Brewer, H.B. (1984): Cardiovascular features of homozygous familial hypercholesterolemia: Analysis of 16 patients. Am. J. Cardiol., 54, 20-30.

8. Kita, T., Yokode, M., Kume, N., Ishii, K., Nagano, Y., Mikami, A., Kita, M., Fujii, K., Kawai, C., Domae, N., Ishihara, H., Kimura, M., and Itokawa, Y. (1988): The concentration of serum lipids in Zen monks and control males in Japan. Jpn. Circ. J., 52, 99-104.

9. West, R., Gibson, P., and Lloyd, J. (1985): Treatment of homozygous familial hypercholesterolemia: An informative sibship. Br. Med. J., 291, 1079-1080.

10. Yamashita, S., Ueyama, Y., Funahashi, T., Nakamura, T., Kawamoto, T., Nakajima, T., Hirobe, K., Matsuzawa, Y., Ishimura, T., and Tarui, S. (1986): A 31-year-old woman with homozygous familial hypercholesterolemia without significant lesions in the coronary arteries. Atherosclerosis, 62, 117-121. 